Energy Research Journal 1 (1): 22-25, 2010

ISSN 1949-0151

(C) 2010 Science Publications

\title{
Effects of Mixing Ratio and Size of Egg-Shell on Boiling and Compression Test of Mixed Charcoal
}

\author{
Bopit Bubphachot, Rujipas Seeladlao and Songchai Wiriyaumpaiwong \\ Faculty of Engineering, Mahasarakham University, Khamriang, Kantarawichai, \\ Maha Sarakham, Thailand 44150
}

\begin{abstract}
Problem statement: The use of waste material is one of the options to add value to the residue. Nowadays, solid fuel development is necessary in current situation due to high price fossil fuel and the reduction of resource. Wood charcoal is widely used in the country which has abundant of forest. Becoming charcoal, it needs to be burnt under optimum condition. However, from this process the loss quality as in the form of breakage charcoal which is the blackish residue consisting of impure carbon is obtained. The price and utilization of this left are less benefit. Therefore, the improvement of charcoal residue by adding egg-shell powder is of interesting. The aim of this research is to study the feasibility of production of compressed charcoal mixed with egg-shell to extend the cooking temperature and time. Approach: Egg-shell was ground and pass through a sieve to get the different particle sizes. Three levels of particle sizes were achieved in the range of 300-600 microns (coarse), 150-300 microns (moderate) and less than 150 microns (fine). For the charcoal, it was obtained from the brakeage charcoal and ground to powder to be substance for making compressed charcoal. The ground charcoal was mixed with egg-shell powder at different ratios of 90:10, 85:15 and 80:20 by weight. The mixture was then compressed as a cylindrical shape by charcoal wet extruder. The formed charcoal was dried by open sun drying and was tested for compressive strength and water boiling. Results: The results showed that egg-shell powder enhanced the thermal property of charcoal regard to the results from water boiling. Conclusion/Recommendations: The best results of the highest compressive strength and the average water temperature were $89 \mathrm{kgf}$ and $90^{\circ} \mathrm{C}$ for $45 \mathrm{~min}$ when application of coarse powder egg-shell at mixing ratio of 85:15.
\end{abstract}

Key words: Waste material, charcoal, egg-shell, wet extruder

\section{INTRODUCTION}

In current economic circumstance, the price of petrol is higher than the past. For developing countries, charcoal and firewood play an important role in rural areas because most population has low income. However, making of charcoal and using of firewood destroy natural resource and release pollutant gases. The good quality biomass charcoal has been investigated regard to compressing process and kinds of biomass. Many kinds of biomass were used as raw materials in the charcoal production, such as rice straw (Thassawong and Unpimpa, 2002), chaff (Jattawa-Pakdee and Promwijit, 2002), corncob (Nahua-Nong and Namwongsa, 2002), cassava tree (Boonsoo and Joompa, 2003), coconut shell (Surin and Laknongbu, 2002). Moreover, the influence of particles size biomass charcoal on the compressive strength and burning behavior was studied (Wiriyaumpaiwong et al., 2004; Seker, 2004; Weert et al.,
2001) due to good thermal storage property. Probably, it can be extended the burning time during cooking.

To reduce the pollutant gases, the blackish residue was reused to produce solid fuel. Furthermore, the eggshell is normally garage waste. In this study, it was chosen as mixed material with blackish residue. Therefore, the improvement of charcoal residue by adding egg-shell powder is interested. The aim of this research is to study the feasibility of production of compressed charcoal mixed with egg-shell by varying amount and partied size of egg-shell powder.

\section{MATERIALS AND METHODS}

There are 2 materials in this experiment, charcoal powder and egg-shell powder. Egg-shell was ground and pass through a sieve to get the different sizes of particle. Three levels of particle sizes were in the range of 300-600 microns (coarse), 150-300 microns

Corresponding Author: Bopit Bubphachot, Faculty of Engineering, Mahasarakham University, Khamriang, Kantarawichai, Maha Sarakham, Thailand 44150 
(moderate) and less than 150 microns (fine). The standard sieve is illustrated in Fig. 1. The details of the mixed ratio are shown in Table 1.

Extrusion machine: The wet charcoal extruder is a forming machine which consists of two main part functions. The first part is the power transmission, a $3 \mathrm{hp}$ gear motor and gear reducer ratio of 1:10 and second part is the charcoal extruder machine which includes screw and cylinder made of hardness SKD 11 steel with a diameter of $120 \mathrm{~mm}$. Screw pitch distance is $30 \mathrm{~mm}$. The mould characteristic is the hexagon shape with each size of $20 \mathrm{~mm}$. The section 3 of the wet charcoal extruder is shown in Fig. 2.

Table 1: The mixed ratio of specimens

\begin{tabular}{lll}
\hline $\begin{array}{l}\text { Particle size of } \\
\text { Charcoal } \\
\text { (micron) }\end{array}$ & $\begin{array}{l}\text { Size of egg-shell } \\
\text { (micron) }\end{array}$ & $\begin{array}{l}\text { Mixed ratio (\%) } \\
\text { charcoal: Egg-shell }\end{array}$ \\
\hline & $<150$ & \\
& $150-300$ & $90: 10$ \\
& $300-600$ & \\
& $<150$ & \\
& $150-300$ & \\
& $300-600$ & \\
& $<150$ & \\
600 & $150-300$ & \\
& $300-600$ & $80: 20$ \\
& & \\
\hline
\end{tabular}

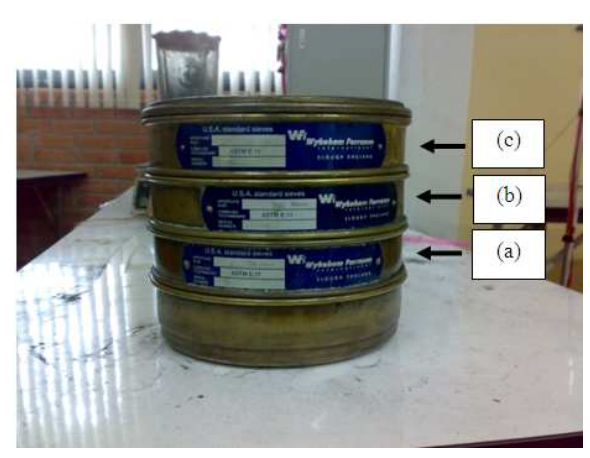

Fig. 1: Standard sieve: (a) the range of 150 microns; (b) the range of 300 microns and (c) the range of 600 microns

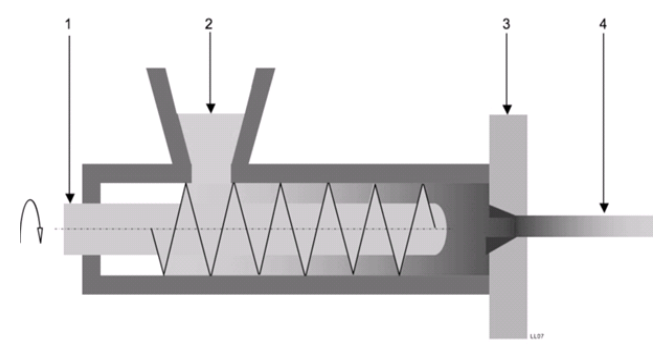

Fig. 2: Section view for the wet charcoal extruder (1) the compression screw; (2) feed hopper; (3) mould and (4) formed charcoal
Water boiling test: The formed charcoal was dried by open sun drying for one day and used to test of water boiling. The testing condition is to boil water of $0.5 \mathrm{~L}$ at the same weight is $0.5 \mathrm{~kg}$ of formed charcoal. Thermocouples ( $\mathrm{k}$ type) which installed at three different positions as shown in Fig. 3 was use to measure water temperature and the water temperature was recorded in every $5 \mathrm{~min}$.

Compression test: There are 3 samples with similar weight and smooth cross-section to be tested for the compressive strength. The testing machine is set a speed of $0.5 \mathrm{~mm} \mathrm{~min}^{-1}$ and then the charcoal is put into the testing machine. The vertical axis of the sample is shown in Fig. 4. The next step is to start the machine, wait until metal plate touch to the top of the sample. The metal plate connected to load cell and set up a Linear Variable Differential Transformer (LVDT). After that, the scales of the load cell and LVDT will be adjusted to zero. Sample data was recorded in details of load and displacement in every $0.01 \mathrm{~mm}$. The machine will stopped when the load is decreased to $75 \%$ of maximum load.

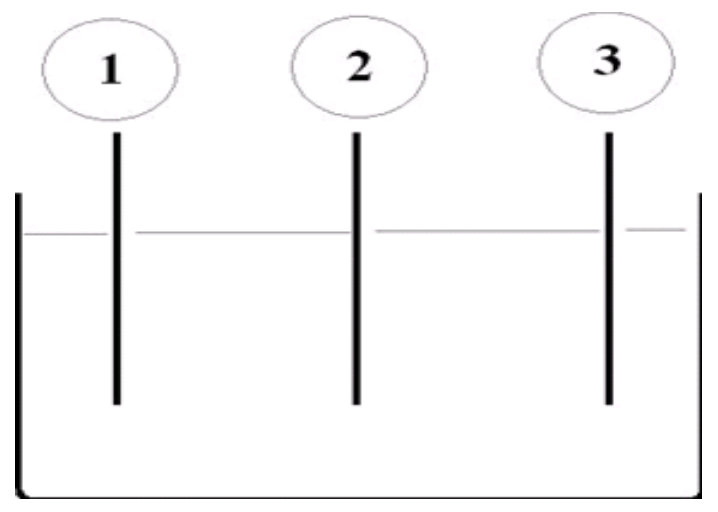

Fig. 3: Measured position of water boiling test

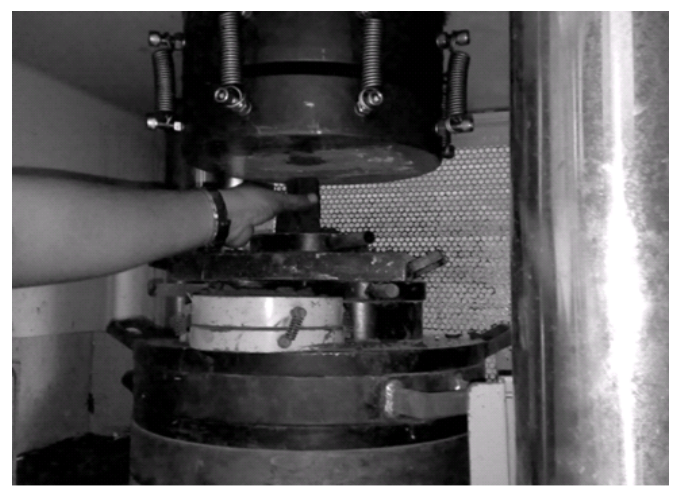

Fig. 4: Compressive strength test 


\section{RESULTS}

Water boiling testing: A comparison of temperature and time of the boiling water using three different sizes of egg-shell powder shows that a charcoal without eggshell powder provided the maximum average temperature. The next are charcoal mixed with eggshell powder's sizes of 300-600 micron, $150-300$ micron and less than 150 micron respectively in Fig. 5.

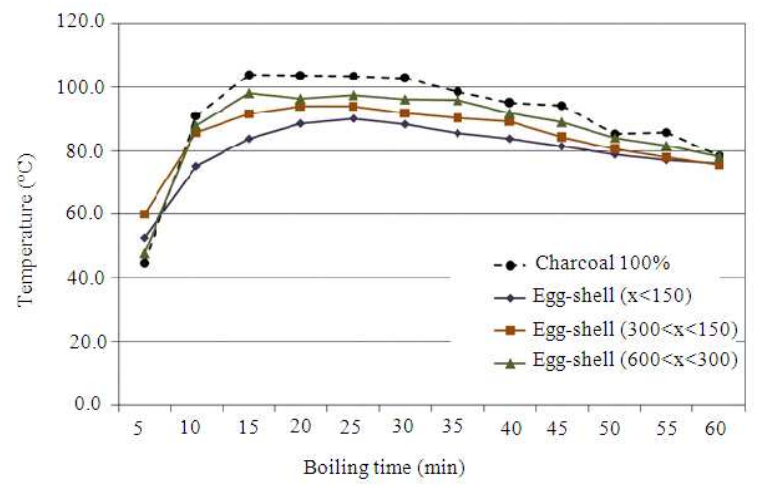

Fig. 5: A comparison of temperature and time of the boiling water using charcoal mixed with eggshell powder in the ratio of 90:10

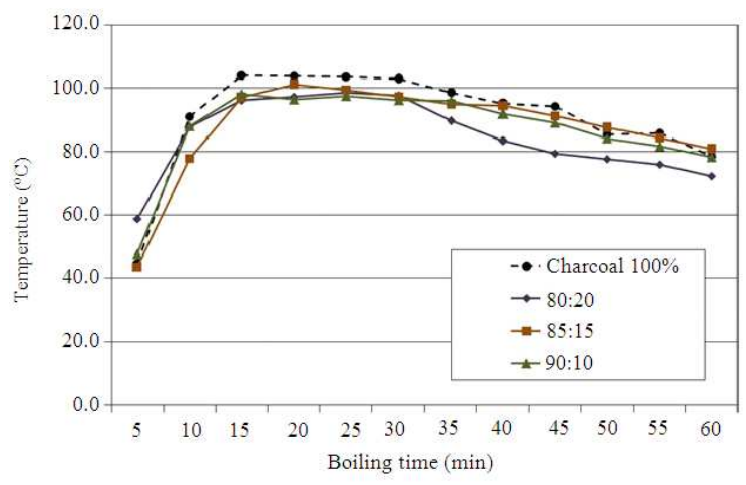

Fig. 6: A comparison of temperature and time of a boiling water using charcoal mixed with eggshell powder's size of 300-600 micron in different ratio

Table 2: The compressive strength of specimens

\begin{tabular}{llll}
\hline $\begin{array}{l}\text { Particle size } \\
\text { of charcoal } \\
\text { (micron) }\end{array}$ & $\begin{array}{l}\text { Size of } \\
\text { egg-shell } \\
\text { (micron) }\end{array}$ & $\begin{array}{l}\text { Mixed ratio } \\
\text { (\%) charcoal: } \\
\text { Egg-shell }\end{array}$ & $\begin{array}{l}\text { Compressive } \\
\text { strength } \\
\left(\mathrm{kg}_{\mathrm{f}}\right)\end{array}$ \\
\hline \multirow{6}{*}{6} & $\mathbf{1 5 0}$ & $90: 10$ & 88.80 \\
& $150-300$ & & 71.10 \\
600 & $300-600$ & & 70.33 \\
& $<150$ & $85: 15$ & 124.30 \\
& $150-300$ & & 99.40 \\
& $300-600$ & & 89.10 \\
& $<150$ & $80: 20$ & 96.50 \\
& $150-300$ & & 88.70 \\
& $300-600$ & & 71.03 \\
\hline
\end{tabular}

Figure 6 shows a comparison of temperature and time of a boiling water using charcoal mixed with eggshell powder's size of 300-600 micron in different ratio. The highest average temperature was obtained at the ratio of 85:15.

Compressive strength testing: From the experiment, Table 2 shows the compressive strength of specimens. An average compressive strength of charcoal mixed with egg-shell powder's size of less than 150 micron was higher than sizes of 150-300 and 300-600 micron respectively.

\section{DISCUSSION}

Water boiling testing: A condition of the experiment was to boil water with an equal weight of the charcoal, the amount of the charcoal in the test was reduced when the ratio of egg-shell powder were increased. However, the difference of the average temperature between the charcoal mixed with egg-shell powder and normal charcoal in every condition was similar. The temperature was increased in the initial step and slightly decreased until the final step as illustrate.

Moreover, the amount of egg-shell powder was higher than other ratios thus, burning this mixed charcoal rapidly produced ash and the temperature was visibly reduced more than others.

Compressive strength testing: A smaller size of eggshell powder can fill gaps in the charcoal better than a bigger size, the smaller size can stand for a high compressive strength.

\section{CONCLUSION}

The ground charcoal was mixed with egg-shell powder at different ratios of 90:10, 85:15 and 80:20 by weight. The mixture was then compressed as a cylindrical shape by charcoal wet extruder. The formed charcoal was dried by open sun drying and was tested for compressive strength and water boiling. The results showed that egg-shell powder enhanced the thermal property of charcoal regard to the results from water boiling. The best results of the highest compressive strength and the average water temperature were 99.4 $\mathrm{kg}_{\mathrm{f}}$ and $90^{\circ} \mathrm{C}$ for $45 \mathrm{~min}$ when application of coarse powder egg-shell at mixing ratio of 85:15.

\section{ACKNOWLEDGMENT}

The researcher would like to express the appreciation to the Faculty of Engineering, 
Mahasarakham University, Mahasarakham Thailand for the financial support.

\section{REFERENCES}

Boonsoo, R. and O. Joompa, 2003. Production of Charcoal from cassava tree. B.S. Thesis, Mahasarakham University, Mahasarakham, Thailand.

Jattawa-Pakdee, N. and S. Promwijit, 2002. Production of charcoal from husk. B.S. Thesis, Mahasarakham University, Mahasarakham Thailand.

Nahua-Nong, T. and H. Namwongsa, 2002. Production of charcoal from cob. B.S. Thesis, Mahasarakham University, Mahasarakham, Thailand.

Seker, M., 2004. Distribution of the residence time in a single-screw extruder with differing numbers of mixing elements. Int. J. Food Sci. Technol., 39: $1053-1060$. DOI: $10.1111 / \mathrm{j} .1365-$ 2621.2004.00888.x
Surin, W. and W. Laknongbu, 2002. Production of charcoal from coconut shell. B.S. Thesis, Mahasarakham University, Mahasarakham, Thailand.

Thassawong, J. and W. Unpimpa, 2002. Production of charcoal from straw. B.S. Thesis, Mahasarakham, University, Mahasarakham Thailand.

Wiriyaumpaiwong, S., C. Tumngam and S. Kodsunghan, 2004. Influence of particle size of biomass coal on combustion. KKU Eng. J., 32: 61-75. http://www.en.kku.ac.th/enjournal/index.php?optio $\mathrm{n}=$ content \&task $=$ view $\& \mathrm{id}=190$

Weert, X., C.J. Lawrence, M.J. Adams and B.J. Briscoe, 2001. Screw extrusion of food powder: Prediction and performance. Chem. Eng. Sci., 56: 1933-1949. DOI: 10.1016/S0009-2509(00)00463-2 